\title{
Influence of social media marketing communications on young consumers' attitudes
}

\author{
Rodney Graeme Duffett
}

\begin{abstract}
Purpose - This paper aims to examine the influence of interactive social media marketing communications on teenagers' cognitive, affective and behavioral attitude components in South Africa. The study also considers the impact of a number of additional factors such as usage (access, length of usage, log-on frequency, log-on duration and profile update incidence) and demographic (gender, age and population group) variables on young consumers' attitudes toward social media marketing communications

Design/methodology/approach - A survey was used via three self-administered questionnaires, which were distributed to over 13,000 learners in the age range of 13-18 years (Generation $Z$ cohort) at colleges and high schools in South Africa. A generalized linear model was used for statistical data analysis.

Findings - The study ascertained that social media marketing communications had a positive on each attitude component among adolescents, but on a declining scale, which correlates to the purchase funnel. The results also revealed that teenagers who used social media for long time periods; updated their profiles frequently and were from the Colored and Black population groups, displayed the most favorable attitudinal responses to social media marketing communications.

Research limitations/implications - Social media was collectively analyzed and did not consider the number of different social media types, which could be examined individually. This investigation only considered the Generation Z cohort, but other cohorts to attitudes toward social media marketing communications could also be assessed.

Practical implications - Companies and their brands should consider using and/or adapting their strategies based on the declining impact of social media marketing communications on the hierarchical attitude stages among young consumers and the divergent influence on usage and demographic variables when targeting the lucrative and technologically advanced, but capricious, Generation $Z$ consumers.

Originality/value - This research established that social media marketing communications had a favorable influence on cognitive, affective and behavioral attitude components among young consumers, but on a declining scale, which is in congruence with the purchase funnel model. This investigation also makes an important contribution to attitudinal research in developing countries, where there is a lack of research in social media marketing communications.
\end{abstract}

Keywords South Africa, Attitudes, Generation Z, Social media marketing communications Paper type Research paper

$\mathrm{T}$ he phenomenal growth of interactive digital technology has impacted almost every aspect of young consumers' daily lives over the past two decades. This new interactive revolution has resulted from noteworthy achievements in the information superhighway (Arens, 2004), known as the Internet, which recently exceeded 3 bn users (Internet World Stats, 2015). Social networking became much quicker with the arrival of the Internet and the globalization that accompanied it, and this gave rise to innovative information communication technology (ICT) channels, which were dubbed social media
Rodney Graeme Duffett is Senior Lecturer at the Department of Marketing, Faculty of Business, Cape Peninsula University of Technology, Cape Town, South Africa.

(C) Cape Peninsula University of Technology. Published by Emerald Publishing Limited. This article is published under the Creative Commons Attribution (CC BY 4.0) licence. Anyone may reproduce, distribute, translate and create derivative works of this article (for both commercial \& non-commercial purposes), subject to full attribution to the original publication and authors. The full terms of this licence may be seen at http://creativecommons.org/ licenses/by/4.0/legalcode

Received 27 July 2016 Revised 29 September 2016 Accepted 16 November 2016 
and/or Web 2.0. But social networking is not a new phenomenon, as it has always been within human nature to communicate and socialize with one another, as well as to recommend, comment and alert each other about commercial content (Uitz, 2012). Hence, a majority of young Internet users also make use of one or more forms of online social media (Barenblatt, 2015). Social media has become an indispensable part of life in the modern-day era, especially among young consumers (teenagers and adolescents) known as Generation Z (also referred to as iGeneration, Plurals and Generation Next) who have enthusiastically adopted this new online ICT platform (McCrindle and Wolfinger, 2009; MacKenzie et al., 2012; James and Levin, 2015).

Social media, such as Facebook, Twitter, Linkedln, YouTube, WhatsApp, Instagram, Tumblr, Pinterest, WeChat and Google+, permit young users to create personalized online pages, communicate and interact with friends, as well as exchange content that they have created themselves (user-generated content) and/or information from other brand-related sources (Matthee, 2011; Statista, 2015). Social behavior and how consumers think have conventionally been disseminated by media such as television, radio, newspapers and magazines, but in the twenty-first century, social media has begun to replace traditional media's enduring and influential role on young consumers. This change in behavior represents both an opportunity and a challenge from an organization's viewpoint (Uitz, 2012; Nhlapo, 2015). Marketers progressively depend more on social and mobile ICT channels to market and promote their brands amid the youth. Additionally, the notion of implementing content that is both entertaining and current would entice young consumers to interact and disseminate the information to their friends. This significant feature, which is also referred to as word-of-mouth (WOM), can be considered as the future of social media marketing communications (Yaakop et al., 2013).

Okazaki and Taylor (2013) report that there was a paucity of definitive theoretical viewpoints in terms of social media as a marketing communication tool because it took time and was a cumulative process to develop theoretical foundations. Bolton et al. (2013) agree that few studies assessed whether there were differences within a separate cohort. Additionally, there are few empirical international inquiries that consider Generation Z. Furthermore, Generation Z's attitudes toward social media marketing communications have not been suitably measured in South Africa. South Africa has become one of the leading regional economic forces in Africa, and joined Brazil, Russia, India and China (BRICS) in 2010. BRICS represent newly industrialized countries with large developing economies and will (and do) play an important role in the world economy (Petzer and De Meyer, 2013). Hoffman and Novak (2012) propose that a sound theoretical framework of social media is required for organizations to implement precise marketing tactics, particularly regarding usage variables such as mobile device access. Peters et al. (2013) suggest that a more holistic approach was required to effectively assess multiple elements of social media to make informed marketing communication decisions.

\section{Research questions}

Hence, this inquiry aims to narrow the gap between theory and practice regarding the different attitude components by addressing the following research questions $(R Q)$ :

$R Q 1$. What influence do social media marketing communications have on young consumers' cognitive, affective and behavioral attitude components?

$R Q 2$. Do usage variables (access, length of usage, log-on frequency, log-on duration and profile update incidence) have an impact on young consumers' attitudes in terms of social media marketing communications?

$R Q 3$. Do demographic variables (gender, age and population group) have an effect on young consumers' attitudes regarding social media marketing communications?

PAGE 20 |YOUNG CONSUMERS | VOL. 18 NO. 12017 


\section{Theoretical background}

Social network sites (SNS) are still relatively new marketing communication tools, which have a significant impact on the way that companies communicate with consumers. Most social media facilitate the use of online marketing communications, which could simply be defined as advertising on the Internet, but is not the same, as mentioned above, owing to the embedded Web 2.0 component that promotes consumer-generated content as a result of information WOM sharing on these platforms (Meyerson, 2010). Online marketing communication, in its simplest form, refers to hyperlinked graphical images that are displayed on a website, and, in recent years, may also include video, audio and a number of other innovative technologies. The primary objectives of online marketing communication usually include creating brand awareness; generating consumer demand; providing information; stimulating traffic; building relationships; promoting two-way communication; giving customer service; establishing brand loyalty; creating WOM; generating leads and increasing sales (Thomas, 2011; Stokes, 2013). Several of these objectives denote various elements of attitude components. The expansion of different online marketing communication formats, in particular the swift growth of social network advertising (SNA), suggests that organizations should be concerned about the attitudes of social media subscribers (Cox, 2010). A number of recent international studies have considered various attitudinal responses toward social media marketing communications (Gensler et al., 2013; Kumar et al., 2013; Malthouse et al., 2013; Tham et al., 2013; Labrecque, 2014; Lukka and James, 2014; Liu et al., 2015). However, these studies mainly used young adults (also known as Millennials or Generation Y) as their research participants, with few considering teenagers. Furthermore, these enquires predominantly occurred in developed economies that have access to good infrastructure, fast broadband Internet speeds, high access levels and sound information technology. Consequently, their online usage characteristics and differing cultural influences may result in significantly different attitudes in comparison to developing countries such as South Africa.

South Africa is a multicultural democracy that embraces diversity and has become known as the "Rainbow Nation" with 11 official languages. However, the deleterious remnants of centuries of ethnic discrimination is still evident in society, economy, culture and politics, and will take many more decades to eradicate than only 20 years of democracy (Fox and Lemon, 2000; Luthans et al., 2004; Hermine, 2014). Nearly 80 per cent of the South Africa's population $(41 \mathrm{mn})$ are Black, which comprise the following main groups: Zulu (28 per cent), Xhosa (20 per cent), Northern Sotho (11 per cent), Tswana (9.7 per cent), Basotho (9.5 per cent), Tsonga (5.5 per cent), Swazi (3.1 per cent) and Venda (2.9 per cent). The Black majority has the lowest average income, education and employment levels, and one in five live below the breadline, but a majority is still confident and optimistic about the future. A sizable middle class group has emerged and continues to grow since South Africa became a democracy in 1994. The Black middle class has greater purchasing power than their White counterparts; access to private schooling and top universities and lucrative employment opportunities because of Black Economic Empowerment, Employment Equity and other Affirmative Action policies (Luthans et al., 2004; Statistics South Africa, 2012; Petzer and De Meyer, 2013; Radebe, 2013; Shevel, 2013; Hermine, 2014; Du Toit, 2015). The new Black middle class is extremely aspirational and seeks status products such as luxury motor vehicles, expensive electronics and household appliances. Black consumers are culturally diverse as they speak different languages and display different beliefs and values (Petzer and De Meyer, 2013). Nearly 9 per cent of South Africans are Colored (4.62 $\mathrm{mn}$ ), which is an extremely racially diverse group comprising of a mixture of Bantu, Khoisan, European, Southeast Asian and Indian ancestry. Coloreds are slightly better off than Black Africans regarding income, education and employment levels, but many feel marginalized because they were not White enough during apartheid and not Black enough after apartheid (Fox and Lemon, 2000; Luthans et al., 2004; Statistics South Africa, 2012; Hermine, 2014). White South Africans form 8.9 per cent of the population 
(4.59 $\mathrm{mn}$ ), but the percentage continues to decline because of lower birthrates and emigration. The White minority have the highest average income, education and employment levels in comparison to the other ethnic groups. A majority remains optimistic about the future of country, but some feel marginalized because of the South African government's Affirmative Action policies making it difficult to find employment (Luthans et al., 2004; Statistics South Africa, 2012; Hermine, 2014). Asians and/or Indians comprise 2.5 per cent (1.29 mn) of the South African population. A majority are Indian and 3,50,000 are Chinese. The Asian/Indian White minority have the second highest average income, education and employment levels in comparison to the other ethnic groups (Statistics South Africa, 2012; Hermine, 2014).

South Africa has a young population, which is evident in many developing countries. Two-thirds are aged 34 years or younger (34.6 mn) and nearly 40 per cent (20.1 mn) are aged 19 years or younger (Statistics South Africa, 2012). Generation Z was the first cohort to have grown up in the post-apartheid era in South Africa and, consequently, this integrated multiracial cohort has greater opportunity than the previous generations. This cohort attends racially mixed schools and has greater access to tertiary education and wealth creation despite the enduring socio-economic and political consequences of apartheid. The South African youth of the present, across cultural groups, are highly independent and ambitious; confident and optimistic; critically conscious and can mobilize themselves robustly; for example, there have been a number of recent "\#" movements where statues, fees, rape [.. .] must fall. However, young South African consumers are extremely image conscious, which has resulted in conspicuous consumption, but are not self-obsessed and care about their future prospects (Duh and Struwig, 2015; Tennant, 2016). Generation Z was born from 1997 onward and has been dubbed as "screen addicts" or "screenagers" who only know a world with continual and instant access to the Internet and social media (Mackenzie et al., 2012; Wharton University of Pennsylvania, 2015; Williams, 2015). Generation Z has more information available at their fingertips than any of the prior generations. Adolescents have grown up in the epoch of computers, the Internet, instant messaging (WhatsApp, WeChat), mobile devices (cell phones, personalized digital assistants, smartphones, tablets, iPods, iPads, iPhones), interactive TV, wireless (Bluetooth), SNS (Facebook, Google+, Linkedln), picture sharing (Instagram, Pinterest, Flickr), micro-blogs (Twitter, Tumblr), video sharing (YouTube, Vine) and many other interactive ICT platforms that enable them to socialize online and assist them with the purchase decision process (Stokes, 2013). Hence, this cohort's e-commerce activities will continue to increase along with their discretionary income, thereby making them a lucrative target market owing to their sheer purchasing power. Young consumers' spending power has already been estimated at $\$ 200$ bn per annum and has a massive influence on household purchases (Heller, 2015). Generation Z had Facebook profiles and Twitter accounts the moment they were born, so social media is as normal as breathing is to them (Wharton University of Pennsylvania, 2015). Generation Z is able to multitask owing to their busy everyday life; show high degrees of creativity, expressiveness and individuality; desire immediacy without long waiting periods for consumption and is generally continually connected via mobile devices and other interactive ICT conduits. These young consumers desire everything, everywhere and instantaneously. However, young consumers are able to quickly filter out boring and irrelevant messages, and rather focus their attention on more creative brand messages. This generation is brand savvy and can rapidly discern unreliable brands (Bevan-Dye and Dondolo, 2014; Barenblatt, 2015; Benhamou, 2015; Williams, 2015). Therefore, it is imperative to acquire a more complete understanding of this generation's attitudes in response to social marketing communications.

For over a century, many advertising models to establish marketing communication objectives have been postulated to represent the attitude phases that consumers might experience before they make a purchase (Barry, 1987). There has been rigorous debate regarding the use of single-component (one-dimensional) and multicomponent models of

PAGE 22 | YOUNG CONSUMERS | VOL. 18 NO. 12017 
attitudes (Bagozzi and Burnkrant, 1980; Barry, 1987; Weilbacher, 2001; Barry, 2002; Maio and Haddock, 2015). However, Bagozzi and Burnkrant (1980) and Barry (2002) found that multicomponent models are valid, and several advocates are in agreement that these models can be used to assess advertising (Barry and Howard, 1990; Durvasula et al., 1993; Brown and Stayman, 1999; Mehta, 2000). Furthermore, there are a myriad of studies (Yoo et al., 2010, Yang, 2012; Gensler et al., 2013; Hamidizadeh et al., 2012; Kumar et al., 2013; Logan et al., 2013; Tan et al., 2013; Labrecque, 2014; Lukka and James, 2014; Boateng and Okoe, 2015; Leung et al., 2015; Liu et al., 2015), which have used multicomponent models to assess attitudes, mainly among young adults, toward social media marketing communications and other digital interactive ICT platforms. Hence, the multicomponent model of attitudes was adopted by this study. Consumers move through successive attitude phases, namely awareness of the brand's existence (cognitive attitude response); knowledge of the brand's offers (cognitive attitude response); liking the brand by having a favorable predisposition to it (affective attitude response); displaying preference toward the brand in relation to others by having a positive attitude to it (affective attitude response); conviction that purchase of the brand would be sensible (behavioral attitude response) and the final purchase of the brand (behavioral attitude response). Ultimately, each attitude phase should be reached, but the stages are essentially not equidistant because consumers can progress though a number of stages concurrently or in a different sequence (Lavidge and Steiner, 1961). Attitudes are relatively enduring, consistent and constant over time and, as described above, comprise three components: cognitive; affective and behavioral (Hamidizadeh et al., 2012). Attitudes toward advertising $\left(A_{a d}\right)$ is a frequently postulated theory that states positive attitudes toward advertising results in analogous attitudes toward the brands, which in turn have a favorable influence on purchase intention (MacKenzie et al., 1986; Bruner and Kumar, 2000). Although, many other variables have been found to have an influence on the $A_{a d}$, such as media usage, age, gender, ethnicity and even mood (MacKenzie and Lutz, 1989). Furthermore, $A_{a d}$ has been considered to be an effective measure of advertising effectiveness (Yoo et al., 2010).

A number of recent international investigations have examined several attitudinal responses toward various types of social media marketing communications. Gensler et al. (2013) report that consumers have become the originators of brand stories owing to the unique nature of networks of brands and consumers that are forged via social media marketing communication, which have resulted in both positive and negative attitudes. Kumar et al. (2013) reveal that WOM social media campaigns lead to a major increase in cognitive and behavioral responses to brands, if consumers who disseminate the marketing content exert a major influence on their social connections. Malthouse et al. (2013) state that social media marketing communication enabled consumers to screen customer relationship management (CRM) messages and advertising, as well as disseminate favorable and positive brand communications. Tham et al. (2013) reveal that WOM distributed via social media was not as credible as traditional WOM, but social media marketing communications provided mechanisms to address unfavorable WOM that was disseminated via traditional and electronic means in terms of tourist destination choices. Lukka and James (2014) found a mixed range of attitudes, which were positive, negative or neutral toward SNA among 465 Bangkok university students who were classified into three clusters accordingly. Murphy (2014) determined that social media resulted in user-generated content that influenced behavioral responses (purchase intentions) favorably among 252 Generation $Y$ respondents in Ireland. However, none of these inquiries considered Generation $Z$ and/or also were mainly conducted in developed countries.

Therefore, in summary, it is important to understand how young online consumers perceive SNA and factors that influence their attitudes because this will determine social media marketing communications content, and will assist to improve the effectiveness of online ICT strategies. This study also investigated a number of usage and demographic variables 
that influence attitude components. The investigation provides additional insight regarding whether social media marketing communications is perceived by young consumers in the same way as traditional advertising, from which these attitude models were developed, and expands the limited pool of knowledge in developing countries that will be valuable to both academics and organizations alike.

\section{Methodology}

This study was empirical, whereby large samples of quantifiable data were collected from young consumers so that the results can be evaluated via statistical analysis to test a theory, which is examined against reality to solve practical research problems (Wright, 2006; Zikmund and Babin, 2007). Hence, this inquiry used survey data to gauge the attitudes of Generation Z toward social marketing communications, which allowed for clearer distinctions from more traditional approaches that were used to effectively reach this group, and elaborated on previous theories on this topic. This inquiry targeted 13-18-year-old high school and college learners (Generation Z) who used and have observed social media marketing communications. The study used a double sampling method, which comprises several phases to draw a sample (Birn, 2004; Blumberg et al., 2011). The research population is first divided into several groups; in this study the Western Cape Province was selected in South Africa. Subsequently, 70 Technical Vocational Education and Training colleges and high schools and were systematically chosen from the Western Cape Education Department's (WCED) list. Both the Cape Peninsula University of Technology and the WCED granted ethical clearance before the study commenced. Thereafter, the colleges and schools were phoned to obtain permission to perform the survey. Nearly 200 learners from each college and high school were selected via systematic sampling, and were requested to participate in the study on a voluntary basis (Gupta, 2010; Bhattacherjee, 2012). Hence, a comprehensive sample was drawn from the Western Cape in South Africa, which was representative of the research population's demographics in terms of gender, population group and age (Statistics South Africa, 2012).

Self-administered questionnaires were distributed to the respondents to immediately complete by themselves, which allowed for more accurate answers, because respondents were able to request assistance if they did not fully understand any of the questions, and completeness, because the fieldworker was able to quickly scan the questionnaire once it was returned (De Vos et al., 2011). Three questionnaires, one for each attitude component, did not ask the Generation Z respondents to identify or list any products or brands, but solely focused on determining their attitudes toward social media marketing communications. This multiple study approach has several advantages: it reduced potential response errors by minimizing the risk of respondents adapting their answers to each attitude phase; it decreased respondent fatigue owing to a shorter questionnaire; it enabled the researcher to "independently" assess each component of the multicomponent model of attitudes; it reduced the potential of ambivalence between the three multicomponent attitude elements; it increased the sample size owing to higher response rates as a result of a shorter questionnaire and provided a full overview of the multicomponent model of attitudes, which resulted in a more comprehensive overview and greater depth of information than a single-attitude component. The research questionnaires consisted of three sections. The first section gathered information relating to the young respondents' social media usage variables (predictor factors) by means of five multiple-choice questions. The next section comprised two eight-item constructs to ascertain one attitude component (cognitive, affective or behavioral). Duffett's (2015c) scales were used for cognitive attitudinal constructs, as well as Duffett's (2015a) scales for the affective attitudinal responses and Duffett's (2015b) scales for the behavioral attitudinal responses. The final section of the questionnaire gathered data pertaining to the young respondents' demographic variables (independent or predictor factors) by means of three multiple-choice questions. A total of 35 fieldworkers (two colleges or schools each) 
collected the data on a face-to-face basis via the self-administered questionnaires, which resulted in an excellent response rate. In this way 13,462 questionnaires were completed, and the data was captured, coded and analyzed via statistical package for the social sciences (SPSS).

\section{Results and analysis}

Table I provides a comprehensive overview of the Generation Z respondents' social media usage and demographic variables.

Adolescents mainly accessed social media via mobile devices (and/or computers), which represented 92.3 per cent of the responses. The massive use of mobile devices among young consumers is a well-known trend that is supported by discourse both locally (Andrews, 2014; Breitenbach, 2015; Harding, 2015; Jovago, 2015) and internationally (Hardwick et al., 2014;

\section{Table I Social media usage and demographic variables}

\begin{tabular}{|c|c|c|c|c|c|c|c|c|}
\hline \multirow{2}{*}{ Usage variables } & \multicolumn{2}{|c|}{ Overall } & \multicolumn{2}{|c|}{ Cognitive } & \multicolumn{2}{|c|}{ Affective } & \multicolumn{2}{|c|}{ Behavioral } \\
\hline & $\mathrm{n}$ & $(\%)$ & $\mathrm{n}$ & $(\%)$ & $\mathrm{n}$ & $(\%)$ & $\mathrm{n}$ & $(\%)$ \\
\hline \multicolumn{9}{|l|}{ Access } \\
\hline Mobile device & 7,726 & 57.4 & 2,984 & 58.8 & 2,328 & 55.7 & 2,414 & 57.4 \\
\hline $\mathrm{PC}$ & 1,035 & 7.7 & 461 & 9.1 & 332 & 7.9 & 242 & 5.8 \\
\hline Mobile Device \& PC & 4,701 & 34.9 & 1,631 & 32.1 & 1,520 & 36.4 & 1,550 & 36.9 \\
\hline \multicolumn{9}{|l|}{ Length of usage } \\
\hline$\leq 1$ year & 2,390 & 17.8 & 1,107 & 21.8 & 721 & 17.2 & 562 & 13.4 \\
\hline 2 years & 2,975 & 22.1 & 1,106 & 21.8 & 934 & 22.3 & 935 & 22.2 \\
\hline 3 years & 3,163 & 23.5 & 1,076 & 21.2 & 998 & 23.9 & 1,089 & 25.9 \\
\hline 4 years & 2,365 & 17.6 & 820 & 16.2 & 738 & 17.7 & 807 & 19.2 \\
\hline$\geq 5$ years & 2,569 & 19.1 & 967 & 19.1 & 789 & 18.9 & 813 & 19.3 \\
\hline \multicolumn{9}{|l|}{ Log-on frequency } \\
\hline Daily & 8,402 & 62.4 & 3,127 & 61.6 & 2,639 & 63.1 & 2,636 & 62.7 \\
\hline 2-4 times a week & 2,793 & 20.7 & 1,033 & 20.4 & 882 & 21.1 & 878 & 20.9 \\
\hline Once a week & 1,295 & 9.6 & 495 & 9.8 & 383 & 9.2 & 417 & 9.9 \\
\hline 2-4 times a month & 571 & 4.2 & 264 & 5.2 & 166 & 4.0 & 141 & 3.4 \\
\hline Once a month & 401 & 3.0 & 157 & 3.1 & 110 & 2.6 & 134 & 3.2 \\
\hline \multicolumn{9}{|l|}{ Log-on duration } \\
\hline$\leq 1 \mathrm{~h}$ & 4,920 & 36.5 & 1,645 & 32.4 & 1,684 & 40.3 & 1,591 & 37.8 \\
\hline $2 \mathrm{~h}$ & 3,273 & 24.3 & 1,209 & 23.8 & 929 & 22.2 & 1,135 & 27.0 \\
\hline $3 \mathrm{~h}$ & 2,425 & 18.0 & 1,014 & 20.0 & 692 & 16.6 & 719 & 17.1 \\
\hline $4 \mathrm{~h}$ & 1,202 & 8.9 & 569 & 11.2 & 338 & 8.1 & 295 & 7.0 \\
\hline$\geq 5 \mathrm{~h}$ & 1,642 & 12.2 & 639 & 12.6 & 537 & 12.8 & 466 & 11.1 \\
\hline \multicolumn{9}{|c|}{ Profile update incidence } \\
\hline Daily & 3,558 & 26.4 & 1,300 & 25.6 & 1,137 & 27.2 & 1,121 & 26.7 \\
\hline 2-4 times a week & 2,867 & 21.3 & 994 & 19.6 & 878 & 21.0 & 995 & 23.7 \\
\hline Once a week & 2,783 & 20.7 & 1,099 & 21.7 & 828 & 19.8 & 856 & 20.4 \\
\hline 2-4 times a month & 1,636 & 12.2 & 742 & 14.6 & 479 & 11.5 & 415 & 9.9 \\
\hline Once a month & 2,618 & 19.4 & 941 & 18.5 & 858 & 20.5 & 819 & 19.5 \\
\hline \multicolumn{9}{|c|}{ Demographic variables } \\
\hline \multicolumn{9}{|c|}{ Gender } \\
\hline Male & 5,854 & 43.5 & 2,179 & 42.9 & 1,784 & 42.7 & 1,891 & 45.0 \\
\hline Female & 7,608 & 56.5 & 2,897 & 57.1 & 2,396 & 57.3 & 2,315 & 55.0 \\
\hline \multicolumn{9}{|l|}{ Age } \\
\hline 13-14 & 2,458 & 18.2 & 664 & 13.1 & 889 & 21.3 & 905 & 21.5 \\
\hline $15-16$ & 5,152 & 38.3 & 1,793 & 35.3 & 1,653 & 39.5 & 1,706 & 40.6 \\
\hline $17-18$ & 5,852 & 43.5 & 2,619 & 51.6 & 1,638 & 39.2 & 1,595 & 37.9 \\
\hline \multicolumn{9}{|l|}{ Population group } \\
\hline White & 1,865 & 13.9 & 542 & 10.7 & 627 & 15.0 & 696 & 16.5 \\
\hline Black & 4,777 & 35.5 & 2,205 & 43.4 & 1,577 & 37.7 & 995 & 23.7 \\
\hline Colored & 6,302 & 46.8 & 2,130 & 42.0 & 1,849 & 44.2 & 2,323 & 55.2 \\
\hline Indian/Asian & 518 & 3.8 & 199 & 3.9 & 127 & 3.0 & 192 & 4.6 \\
\hline
\end{tabular}


Pescher et al., 2014; Kantar Media, 2015; Pew Research Centre, 2015). Teenagers' social media length of usage was relatively evenly spread between one and five years. This is a rational result because younger adolescents would have been using SNS for a shorter time frame owing to age restrictions on SNS such as Facebook (Facebook, 2016). Furthermore, a majority of the South population is categorized as previously disadvantaged individuals (PDIs) (Black, Colored and Indian/Asian) because of apartheid, and therefore, many PDI Generation Z only gain access to the Internet and social media later in life owing to financial constraints (De Lanerolle, 2012; Lesame, 2013; Petzer and De Meyer, 2013). Generation Z primarily logged on to social media daily or several times a week (83.1 per cent), which is equivalent to other global (Lukka and James, 2014; Murphy, 2014; Benhamou, 2015) and local (Dlodlo and Dhurup, 2013; Wronski, 2015) research. Most South African teenagers spend $1-2 \mathrm{~h}$ (60.8 per cent) on social media per log-in, but many log-ins several times a day via the ubiquitous mobile phones (Azzie, 2014), which would increase the total time spent on SNS (Dlodlo and Dhurup, 2013), although this phenomenon was not considered in this study. A majority of young consumers in South Africa update their social media profiles daily or weekly (68.4 per cent), with over a quarter updating on a daily basis. This usage variable has not been assessed in prior research, and hence, this study produced some original findings in terms of cross-analysis with the three attitude components that are elaborated upon in later text.

Female adolescents that use social media were in the ascendancy (56.5 per cent), which corresponds with the South African population (Statistics South Africa, 2012). The older Generation Z members (15-18 - year-olds) collectively accounted for nearly 82 per cent of social media users, which is a logical result owing to the age restrictions of certain social media (e.g. Facebook) or the lack of Internet access in their early teens, which was mentioned in prior text. There is a lack of research within cohorts, as mandated by Bolton et al. (2013); therefore, this inquiry provided some unique findings in terms of social media marketing communications attitudinal research. The population groups essentially duplicated the cultural diversity of teenagers who live in the Western Cape in South Africa; therefore, Black (35.5 per cent) and Colored (46.8 per cent) adolescents accounted for a majority of the sample (Statistics South Africa, 2012). Table I offers a complete summary of usage and demographic variables of young consumers who use social media.

Table II reveals that the initial attitude components, such as awareness and knowledge, display higher means that progressively decrease for each sequential attitudinal response toward social media marketing communications amid South African teenagers, until culminating in the eventual purchase. This notion evidently mirrors the purchase funnel, which postulates that each attitude component becomes increasingly more demanding to achieve, with the number of potential consumers decreasing as they progress down the funnel, until the final primary marketing communication objective, namely purchase (Safko, 2010; Belch and Belch, 2015). Though, the purchase funnel was developed via traditional media marketing communications research that is generally one-way communication, conversely, social media is primarily interactive in nature (Ma and Liu, 2010). Therefore, this study empirically substantiates that in spite of the high levels of consumer engagement and

Table II Social media marketing communication attitude constructs

\begin{tabular}{lcccc} 
Attitude components & Mean & SD & Cronbach's $\alpha$ & $\mathrm{p}$ \\
\hline Awareness (cognitive) & 3.39 & 0.775 & 0.881 & $0.000^{*}$ \\
Knowledge (cognitive) & 3.35 & 0.742 & 0.845 & $0.000^{*}$ \\
Liking (affective) & 3.17 & 0.675 & 0.806 & $0.000^{*}$ \\
Preference (affective) & 3.08 & 0.618 & 0.795 & $0.000^{*}$ \\
Intention-to-purchase (behavioral) & 2.89 & 0.770 & 0.895 & $0.000^{*}$ \\
Purchase (behavioral) & 2.83 & 0.613 & 0.811 & $0.000^{*}$ \\
Note: * Wald's chi-square test showed a significant difference at $p<0.001$ &
\end{tabular}

PAGE 26 |YOUNG CONSUMERS | VOL. 18 NO. 12017 
two-way communication of social media among Generation Z; these interactive ICT platforms still adhere to the principles of communications effects pyramid.

Cronbach's Alpha coefficient is a universally accepted measure of reliability and scores should be above 0.7, whereas scores over 0.8 show good internal consistency levels (Pallant, 2010). Cronbach's Alpha coefficient shows that the each attitude stage has an acceptable and good internal consistency level, with scores ranging from 0.795 to 0.895 (Table II and Appendix). ANOVA was used to establish if there was any significance in terms of the different means, though Wald's Chi-square distribution statistic and a generalized linear model was used to ascertain if there were significant differences between the dependent (attitude components) and independent (usage and demographic factors) variables (Maree, 2007; Pallant, 2010). Table II indicates that there were statistically significant outcomes for each of the attitude stages in terms of social media marketing communications among adolescents in South Africa at $p<0.001$. Hence, this study demonstrates that social media marketing communications enables organizations and their brands to reach young consumers, particularly the notorious vacillating Generation Z.

\section{Discussion}

\section{Social media marketing communications' influence on young consumers' attitudes}

Several other international inquiries have considered various aspects of social media marketing communications related to different attitude components across a number of cohorts and industries. Schivinski and Dabrowski (2015) discovered that both user-generated and organizational social media brand communications positively affected awareness (cognitive responses). Labrecque's (2014) inquiry determined that brand interaction in different social media settings resulted in positive cognitive attitudinal responses among a total of 380 respondents in the USA in three separate studies. The study resulted in positive cognitive attitudinal responses regarding brand interaction in social media settings. Kabadayi and Price (2014) disclosed different types of individual and mass communication interaction on Facebook and personality traits influenced affective responses in the form of liking and comments among 269 Millennial respondents in the USA. Tan et al. (2013) learned that there was a positive association between purchase SNA effectiveness and behavioral responses (purchase intentions) among 149 Malaysian students. Hardwick et al.'s (2014) research yielded negative and positive behavioral attitudinal responses toward SNA for mobile phone purchases among 25 respondents in the United Kingdom. Liu et al. (2015) examined factors that influenced the effectiveness of social media product placement. The investigation established videos with subtle product placements, which resulted in the most favorable attitude and behavioral responses, and that the effect of social media product placements was comparable to other media. However, this study shows that young consumers share analogous positive attitudes toward social media marketing communications, with a majority of the aforementioned inquiries in spite of the fact that they were largely executed in first-world countries among older generational cohorts.

\section{Usage variables' effect on young consumers' attitude components}

Social media marketing communications resulted in the most positive cognitive and affective attitudinal responses when accessed via mobile devices amid Generation Z (refer to Table III). This is not an unexpected result, because Swanepoel (2015) also established that mobile channels had become the most popular marketing communications platform in Africa, with over 90 per cent having access to a mobile network. Harding (2015) disclosed that the use of mobile devices to purchase online increased from 23 per cent in 2013 to over 46 per cent in 2014, whereas the use of computers declined from 94.7 per cent in 2013 to 63.6 per cent in 2014. It is clear from the above discussion that the rapid proliferation of 


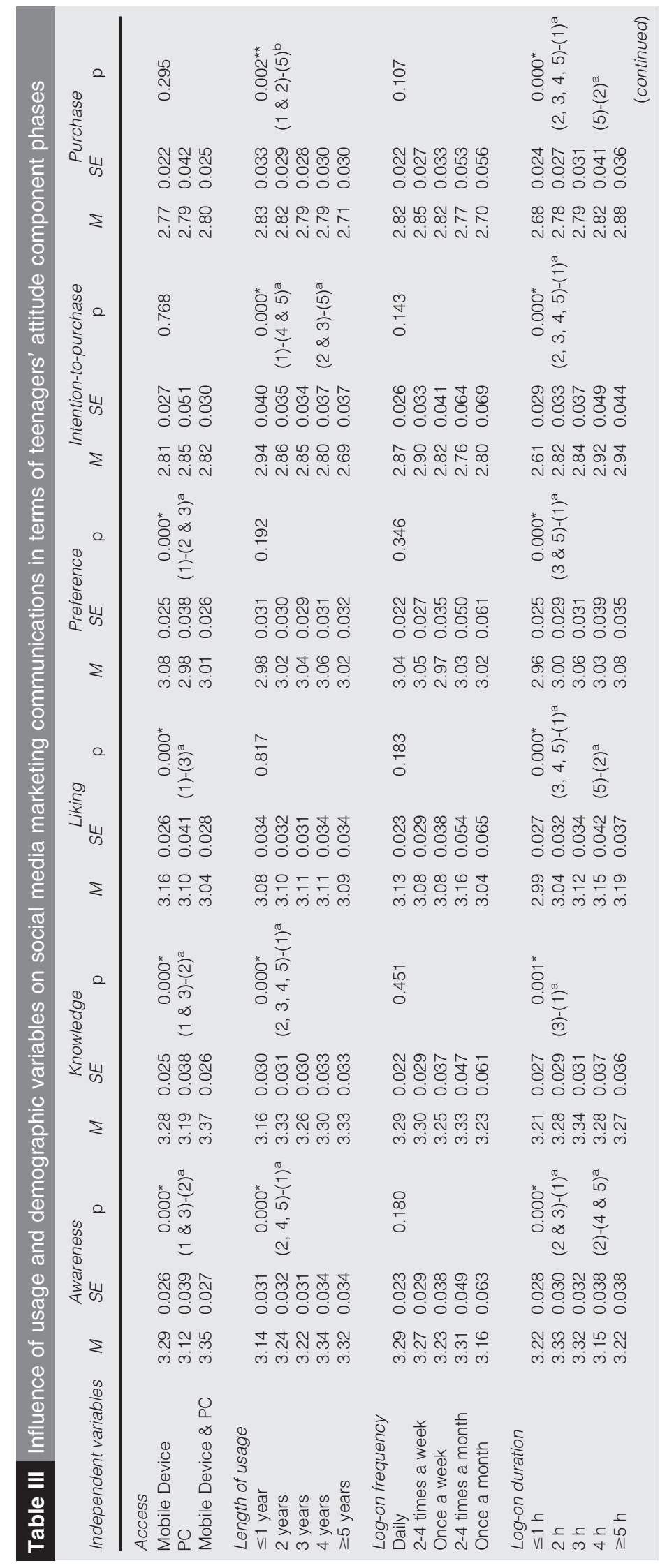




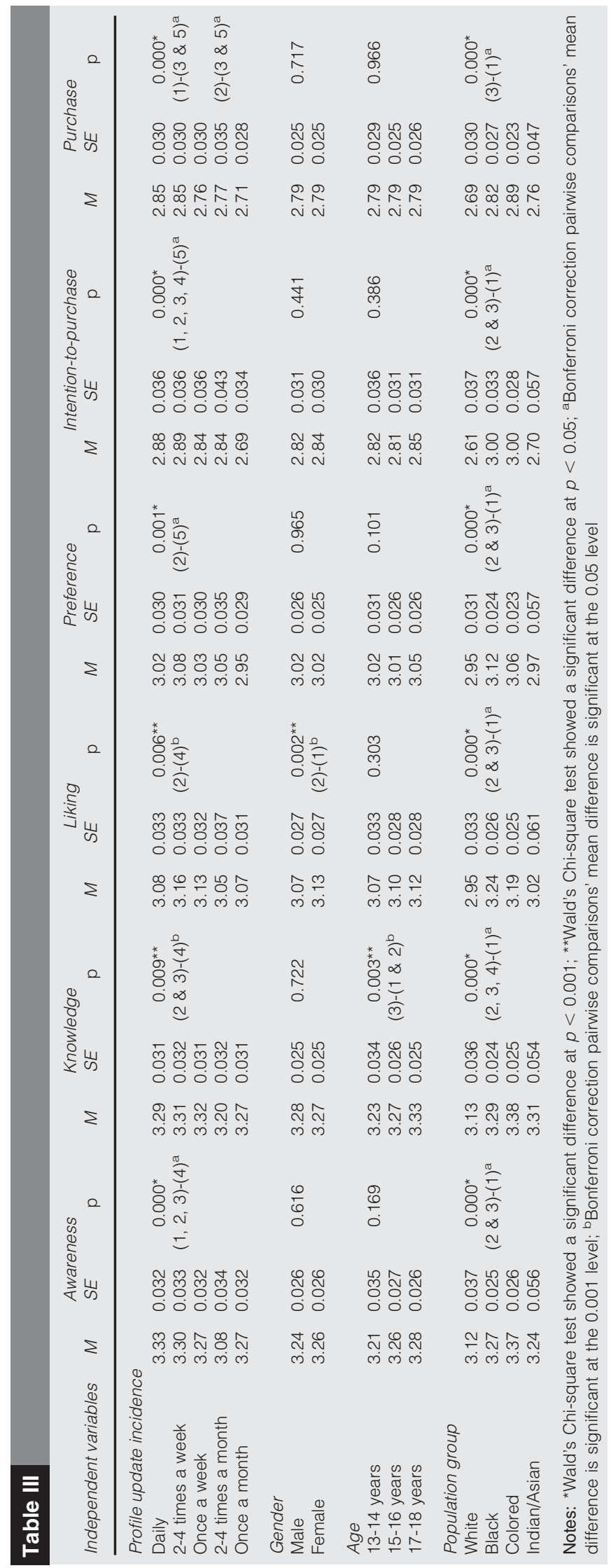


smartphones and other mobile devices has resulted in tremendous growth among user numbers that access social media via mobile devices in Africa and South Africa. This enables astute marketers to continually stream relevant and interested content via social media marketing communications to teenagers who have never known a world without SNS and smartphones (Barker et al., 2013; Williams, 2015).

Adolescents who had used social media for 2 years or more displayed the most favorable cognitive attitudes toward SNA, whereas, conversely, those young consumers who had used social media for 1 year or less exhibited the greatest positive behavioral attitudes toward SNA (refer to Table III). Balabanis and Vassileiou (1999), Liao and Cheung (2001) and Sago (2013) confirmed that the experience levels of online users affected attitude components for an array of interactive ICT channels. It is apparent that more experienced teenagers had become accustomed to social media marketing communications because their higher attitude components were not as readily positively affected as those with less familiarity who were, therefore, found to be more susceptible in this study (Cox, 2010). Therefore, organizations and their brands should continually provide accurate and recent content to Generation Z, who is able to absorb information instantly, but may also lose interest quickly if it does not stimulate engagement (Williams, 2015).

The log-on frequency usage variable did not result in any significant difference regarding attitudinal responses (Table III). Chandra et al. (2012) established that there was no difference in terms of cognitive and affective responses between frequent and sporadic users toward social media marketing communications, which is in line with the results of this study. However, the mean values indicate that adolescents who logged on more frequently (daily and several times a week) showed the most favorable predispositions across all of the attitude stages toward social media marketing communications. Maddox and Gong (2005) also posited that the most active Internet users displayed the largest inclination to use commercial content available online to assist with purchase decisions.

Teenagers who spent longer periods of time (two or more hours) on social media manifested favorable cognitive, affective and behavioral attitudes toward marketing communications (refer to Table III). This result is a rational supposition because the longer time adolescents spend on social media, the more likely they will view and interact with marketing communications on these digital ICT conduits. Bridges et al. (2009) also implied that the longer marketing communications were displayed, the greater the likelihood that it would have a positive effect on buying decisions. Organizations and their brands should, therefore, encourage young social media users to stay online for longer periods of time via branded apps, games and competitions and many other interactive promotional tools to develop favorable attitudinal responses.

Generation Z social media users who updated their profile more regularly (daily and several times a week) displayed the most positive sentiments toward marketing communications across all attitude stages (refer to Table III). Again, this is a reasonable notion because the more teenagers interact on social media, the greater the probability that they will all interact with marketing communications on these interactive ICT platforms. However, the profile update incidence has not been considered in prior studies in terms of this usage variable's influence on social media marketing communications regarding attitudinal responses. Therefore, this is a pioneering inquiry that has made a noteworthy addition to SNS research among young consumers from a practical and theoretical perspective.

\section{Demographic variables' effect on young consumers' attitude components}

The gender demographic variable did not have a large influence on the attitude components although female teenagers displayed higher levels of liking (affective attitude) in terms of social media marketing communications (refer to Table III). Bannister et al. (2013) and Ruane and Wallace (2013) also revealed that males exhibited less favorable attitudes than women regarding social media marketing communications, which is 
consistent with the results of this investigation for Generation Z. Hence, organizations should take advantage of the fact that female adolescents also participate in a greater quantity of social media activities and are more probable to have favorable affective attitudes toward SNA (Walter, 2014).

The age demographic variable also demonstrated a limited influence on attitude components with the exception of knowledge (cognitive attitude) as a result of social media marketing communications, where older teenagers (17-18 years old) display more favorable sentiments than their younger counterparts (refer to Table III). Furthermore, the mean values also suggest that older adolescents have more favorable responses across all of the other attitude components toward social media marketing communications. Moore (2012) also established that older cohorts reflected more positive behavioral responses than younger cohorts on different interactive online ICT platforms, which is a rational notion because older consumers would have larger financial resources. Mulero and Adeyeye (2013) posited that social network marketing was predominantly used and accepted by younger respondents. Yet, neither of the abovementioned studies considered teenagers or age classifications within a single cohort regarding attitude components toward social media marketing communications; hence, this study has made a preliminary contribution to academic discourse.

PDI adolescents exhibited the most favorable predispositions across all attitude components owing to social media marketing communications in comparison to their White compatriots (refer to Table III). This is a reasonable supposition because Black middle class has grown considerably, since apartheid was abolished, and their spending power now exceeds that of their White counterparts. However, a significant percentage of PDIs in South Africa still lives in poverty and/or are unemployed, but they are able to access social media via mobile devices (Petzer and De Meyer, 2013; Radebe, 2013; Shevel, 2013; Du Toit, 2015). Shevel (2013) reported that over three-quarters of the Black middle class adolescents attend private or former "model C" schools, which has increased the number of PDI Generation Z social media users. Furthermore, Grier and Deshpande (2001) established that Black South Africans displayed a higher probability of being favorably influenced by advertising. However, White teenagers generally have greater levels of social media experience than PDIs who may, therefore, be more susceptible to marketing communications on these interactive ICT conduits. However, few local or international studies have considered the effect of population groups on SNA regarding attitudes components. Hence, this innovative investigation has made a significant contribution to both the development of theoretical and practical perspectives on social media and attitudinal research.

\section{Conclusion and implications}

Teenagers have become largely resistant to traditional marketing; hence, advertising revenues for many above-the-line media have slowed in growth or even declined in recent years, whereas several forms of digital interactive advertising (in particular mobile and social media) have proved to be resilient to the fickleness of this younger generation, as well as the overall economic conditions of the market, and so has seen steady growth over the past decade (Lazarevic, 2012; Jaffit, 2015; Pombo, 2015). The emergence of interactive social media has made it possible for marketers to communicate to millions of young consumers about their products; consequently, the impact of consumerto-consumer communication has been greatly magnified in the marketplace. No organization can develop without an effective marketing communication strategy for their brands to create favorable attitudinal responses among their consumers or users, which begins with awareness and knowledge, and progresses through several other components that ultimately climax in a predisposition to purchase. A number of organizations and their brands have used social media to promote their brands and engage with young customers amid an explosion of digital ICT platforms in South Africa and abroad. However, many organizations and their brands have used social media marketing communications without 
truly understanding the real influence that these digital ICT conduits exert on young consumers' attitudinal responses or whether and what usage and demographic variables have a favorable influence on Generation Z's predispositions.

This investigation established that social media marketing communications had a significant effect on every attitude component, but the mean value declined with each successive stage. These findings correspond with the sales funnel principles that were developed via traditional advertising and verified that SNA resulted in analogous attitudes among young consumers. A number of usage and demographic variables had a major influence on the attitude components of South African teenagers. The most noteworthy elements of these findings ascertained that adolescents who accessed social media via mobile devices for protracted periods of time (more than $2 \mathrm{~h}$ ) and updated their profiles on a daily basis exhibited the greatest positive responses across most of the attitude components toward marketing communications on these interactive ICT channels. Furthermore, older female PDI teenagers were also more likely to display the most favorable attitudes toward social media marketing communications. This study has aided to reduce the academic-practitioner gap regarding the attitude-to-advertising $\left(A_{a d}\right)$, and cohort theories by making a noteworthy contribution to social media research from both a global and African viewpoint, which should serve as a platform and catalyst for future inquiry. However, Kaushik (2009) notes that "social media is like teen sex. Everyone wants to do it. Nobody knows how. When it's finally done there is surprise it's not better". The same sentiments are applicable to marketing communications on social media, with a significant quantity of research still necessary to fully understand the implications of these interactive ICT channels' effects on young consumers.

\section{Limitations and further research}

This study does have several limitations, which provides possibilities for future investigations. There are a number of different social media types that are used by Generation Z, but these interactive ICT platforms were collectively analyzed in this inquiry, which could also be examined individually. This investigation did not consider examining specific brand advertising, but examined social media marketing communications generically, which may also provide a channel for additional research. Generation Z are the heavy social media users, but a comparison of attitudinal responses from other cohorts to SNA could be assessed. This research only considered South Africa, which is an emerging country with its own set of unique and diverse cultural influences. However, other developing and developed nations should be investigated to ascertain if Generation Z does indeed share homogeneous predispositions toward social media marketing communications.

\section{References}

Andrews, L. (2014), "Insights into the average South African mobile phone user", available at: www. bizcommunity.com/Article/196/78/121069.html\#more (accessed 23 June 2016).

Arens, W.F. (2004), Contemporary Advertising, 9th ed., McGraw-Hill Irwin, New York, NY.

Azzie, A. (2014), "Millennials - are online marketers missing the mark?", available at: www. bizcommunity.com/Article/196/16/121887.html (accessed 26 June 2016).

Bagozzi, R.P. and Burnkrant, R.E. (1980), "Single component versus multicomponent models of attitude: Some cautions and contingencies for their use", Advances in Consumer Research, Vol. 7 , pp. 339-344.

Balabanis, G. and Vassileiou, S. (1999), "Some attitudinal predictors of home-shopping through the Internet”, Journal of Marketing Management, Vol. 15, pp. 361-385.

Bannister, A., Kiefer, J. and Nellums, J. (2013), "College students' perceptions of and behaviours regarding Facebook advertising: an exploratory study", The Catalyst, Vol. 3 No. 1, pp. 1-20. 
Barenblatt, C. (2015), "Marketing to millennials", available at: www.bizcommunity.com/Article/196/ 347/123834.html\#more (accessed 21 July 2016).

Barker, M., Barker, D., Bormann, N. and Neher, K. (2013), Social Media Marketing: A Strategic Approach, International Ed., South-Western, Cengage Learning, Mason, $\mathrm{OH}$.

Barry, T.E. (1987), "The development of the hierarchy of effects: an historical perspective", Current Issues and Research in Advertising, Vol. 10 No. 2, pp. 251-295.

Barry, T.E. (2002), "In defense of the hierarchy of effects: a rejoinder to Weilbacher", Journal of Advertising Research, Vol. 42 No. 3, pp. 44-47.

Barry, T.E. and Howard, D.J. (1990), "A review and critique of the hierarchy of effects in advertising", International Journal of Advertising, Vol. 9 No. 2, pp. 121-135.

Belch, G.E. and Belch, M.A. (2015), Advertising and Promotion: An Integrated Marketing Communication Perspective, 10th ed., McGraw-Hill, Singapore.

Benhamou, L. (2015), "Everything you need to know about Generation Z", available at: www. businessinsider.com/afp-generation-z-born-in-the-digital-age-2015-2 (accessed 18 July 2016).

Bevan-Dye, A.L. and Dondolo, B. (2014), "Enigma generation - Generation Y", available at: www. bizcommunity.com/Article/196/19/117207.htm|\#more (accessed 16 July 2016).

Bhattacherjee, A. (2012), Social Science Research: Principles, Methods, and Practices, USF Tampa Bay Open Access Textbooks, Tampa, FL.

Birn, R.J. (2004), The Effective Use of Market Research, 4th ed., Kogan Page, London.

Blumberg, B., Cooper, D.R. and Schindler, P.S. (2011), Business Research Methods, 3rd ed., McGraw-Hill, London.

Boateng, H. and Okoe, A.F. (2015), "Consumers' attitude towards social media advertising and their behavioural response", Journal of Research in Interactive Marketing, Vol. 9 No. 4, pp. 299-312.

Bolton, R.N., Parasuraman, A., Hoefnagels, A., Migchels, N., Kabadayi, S., Gruber, T., Loureiro, Y.K. and Solnet, D. (2013), "Understanding Generation $Y$ and their use of social media: a review and research agenda", Journal of Service Management, Vol. 24 No. 3, pp. 245-267.

Breitenbach, D. (2015), "Mobile, mobile, mobile", available at: www.bizcommunity.com/Article/196/ 78/131191.html (accessed 18 June 2016).

Bridges, E. Briesch, R.A. and Shu, S.B. (2009), "The impact of advertising of child adult and all family RTE cereal markets", available at: http://citeseerx.ist.psu.edu/viewdoc/download;jsessionid=98849 E518030408B09F97EFC14B13229?doi=10.1.1.111.9627\&rep=rep1\&type =pdf (accessed 18 July 2016).

Brown, S. and Stayman, D. (1999), "Antecedents and consequences of attitude toward the ad: a meta-analysis", Journal of Consumer Research, Vol. 19, pp. 24-51.

Bruner, G.C. and Kumar, A. (2000), "Web commercials and advertising hierarchy-of-effects", Journal of Advertising Research, Vol. 40 Nos 1/2, pp. 35-42.

Chandra, B., Goswami, S. and Chouhan, V. (2012), "Investigating attitude towards online advertising on social media - an empirical study", Management Insight, Vol. 8 No. 1, pp. 1-14.

Cox, S.A. (2010), "Online social network attitude toward online advertising formats", Master dissertation, The Rochester Institute of Technology, Rochester, NY.

De Lanerolle, I. (2012), The New Wave: Who Connects to the Internet, How They Connect and What They do When they Connect, South African Network Society Project and University of Witwatersrand, Johannesburg.

De Vos, A.S., Strydom, H., Fouché, C.B. and Delport, C.S.L. (2011), Research at Grass Roots, 4th ed., Van Schaik, Pretoria, SA.

Dlodlo, N. and Dhurup, N. (2013), "Examining social media dimensions among a cohort of Generation Y consumers in South Africa", Mediterranean Journal of Social Sciences, Vol. 4 No. 14, pp. 329-338.

Du Toit, P. (2015), "How brands can reach black consumers", www.bizcommunity.com/Article/196/4 23/127216.html (accessed 21 June 2016). 
Duffett, R.G. (2015a), "Effect of Gen Y's affective attitudes towards Facebook marketing communications in South Africa", Electronic Journal of Information Systems in Developing Countries, Vol. 68 No. 2, pp. 1-27.

Duffett, R.G. (2015b), "Facebook advertising's influence on intention-to-purchase and purchase amongst Millennials", Internet Research, Vol. 25 No. 4, pp. 498-526.

Duffett, R.G. (2015c), "The influence of Facebook advertising on cognitive attitudes amid Generation Y”, Electronic Commerce Research, Vol. 15 No. 2, pp. 243-267.

Duh, H. and Struwig, M. (2015), "Justification of generational cohort segmentation in South Africa", International Journal of Emerging Markets, Vol. 10 No. 1, pp. 89-101.

Durvasula, S., Andrews, J.C., Lysonski, S. and Netemeyer, R.G. (1993), "Assessing the cross-national applicability of consumer behaviour models: a model toward advertising in general", Journal of Consumer Research, Vol. 19, pp. 626-636.

Facebook (2016), "Facebook adverts guide", available at: www.facebook.com/business/ads-guide/? tab0=Mobile\%20News\%20Feed (accessed 24 July 2016).

Fox, R. and Lemon, A. (2000), "Consolidating South Africa's new democracy: Geographical dimensions of party support in the 1999 elections", Journal of Economic and Social Geography, Vol. 91 No. 4, pp. 347-360.

Gensler, S., Völckner, F., Liu-Thompkins, Y. and Wiertz, C. (2013), "Managing brands in the social media environment", Journal of Interactive Marketing, Vol. 27 No. 4, pp. 242-256.

Grier, S. and Deshpande, R. (2001), "The influences of social status on group identity and social status", Journal of Marketing Research, Vol. 38 No. 2, pp. 216-224.

Gupta, S.L. (2010), Marketing Research, Excel Books, New Delhi.

Hamidizadeh, M.R., Yazdani, N. Tabriz, A.A. and Latifi, M.M. (2012), "Designing and validating a systematic model of e-advertising", International Journal of Marketing Studies, Vol. 4 No. 2, pp. 130-149.

Harding, W. (2015), "The state of e-commerce in South Africa", available at: www.bizcommunity.com/ Article/196/394/126894.html\#more (accessed 28 June 2016).

Hardwick, J., Delarue, L., Ardley, B. and Taylor, N. (2014), Computer-Mediated Marketing Strategies: Social Media and Online Brand Communities, University of Lincoln and Business School IGI Global, Lincoln.

Heller, L. (2015), "Move over Millennials, Generation Z is in charge", available at: www.forbes.com/ sites/lauraheller/2015/08/14/move-over-millennials-generation-z-is-in-charge/ (accessed 29 June 2016).

Hermine, G.L. (2014), "Race, ethnicity and language in South Africa", available at:https://welections. wordpress.com/guide-to-the-2014-south-african-election/race-ethnicity-and-language-in-south-africa/ (accessed 28 September 2016).

Hoffman, D.L. and Novak, T.P. (2012), "Toward a deeper understanding of social media", Journal of Interactive Marketing, Vol. 26 No. 2, pp. 69-70.

Internet World Stats (2015), "World Internet users and population statistics", available at: www. internetworldstats.com/stats.htm (accessed 2 July 2016).

Jaffit, D. (2015), "Marketing to millennials", available at: www.bizcommunity.com/Article/196/423/127 064.html (accessed 20 June 2016).

James, A. and Levin, J. (2015), "Digital natives: a portrait of tech and urban youth", Sunday Times Generation Next 2015, May, p. 16.

Jovago (2015), "The mobile revolution in Africa", available at: www.bizcommunity.com/Article/196/78/ 127099.html\#more (accessed 28 June 2016).

Kabadayi, S. and Price, K. (2014), "Consumer - brand engagement on Facebook: liking and commenting behaviors", Journal of Research in Interactive Marketing, Vol. 8 No. 3, pp. 203-223.

Kantar Media (2015), "Boomers underindex for smartphone ownership by a wide margin", available at: www.emarketer.com/Article/Boomers-Underindex-Smartphone-Ownership-by-Wide-Margin/1013177? ecid=NL1002 (accessed 18 June 2016). 
Kaushik, A. (2009), "Quote of the day: social media is like teen sex", available at: www.cnet.com/ news/quote-of-the-day-social-media-is-like-teen-sex/ (accessed 2 July 2016).

Kumar, V., Bhaskaran, V., Mirchandani, R. and Shah, M. (2013), "Creating a measurable social media marketing strategy: increasing the value and ROI of intangibles and tangibles for hokey pokey", Marketing Science, Vol. 32 No. 2, pp. 194-212.

Labrecque, L.I. (2014), "Fostering consumer-brand relationships in social media environments: the role of parasocial interaction", Journal of Interactive Marketing, Vol. 28 No. 2, pp. 134-148.

Lavidge, R.J. and Steiner, G.A. (1961), "A model of predictive measurement of advertising effectiveness", Journal of Marketing, Vol. 25 No. 6, pp. 59-62.

Lazarevic, V. (2012), "Encouraging brand loyalty in fickle Generation Y consumers", Young Consumers, Vol. 13 No. 1, pp. 45-61.

Lesame, N. (2013), "Vision and practice: the South African information society experience", Journal of Multidisciplinary Research, Vol. 5 No. 1, pp. 73-90.

Leung, X.Y., Bai, B. and Stahura, K.A. (2015), "The marketing effectiveness of social media in the hotel industry: a comparison of Facebook and Twitter", Journal of Hospitality \& Tourism Research, Vol. 39 No. 2, pp. 147-169.

Liao, Z. and Cheung, T. (2001), "Internet-based e-Shopping and consumer attitudes: an empirical study", Information and Management, Vol. 38, pp. 299-306.

Liu, S., Chou, C. and Liao, H. (2015), "An exploratory study of product placement in social media", Internet Research, Vol. 25 No. 2, pp. 300-316.

Logan, K., Bright, L.F. and Gangadharbatla, H. (2013), "Facebook vs television: advertising value perceptions among females", Journal of Research in Interactive Marketing, Vol. 6 No. 3, pp. 164-179.

Lukka, V. and James, P.T.J. (2014), "Attitudes toward Facebook", Journal of Management and Marketing Research, Vol. 14, pp. 1-26.

Luthans, F., Van Wyk, R. and Walumbwa, F.O. (2004), "Recognition and development of hope for South African organizational leaders", Leadership \& Organization Development Journal, Vol. 25 No. 6, pp. 512-527.

McCrindle, M. and Wolfinger, E. (2009), The ABC of XYZ: Understanding the Global Generations, UNSW Press, New South Wales, AU.

MacKenzie, J., McGuire, R. and Hartwel, S. (2012), "The first generation of the twenty-first century", available at: http://magid.com/sites/default/files/pdf/MagidPluralistGenerationWhitepaper.pdf (accessed 3 July 2016).

MacKenzie, S.B. and Lutz, R.J. (1989), "An empirical examination of the structural antecedents of attitude toward the ad in an advertising pretesting context", Journal of Marketing, Vol. 53 No. 2, pp. 48-65.

MacKenzie, S.B., Lutz, R.J. and Belch, G.E. (1986), "The role of attitude toward the ad as a mediator of advertising effectiveness: a test of competing explanations", Journal of Marketing Research, Vol. 23 No. 2, pp. 130-143.

Ma, J. and Liu, H. (2010), "Advertising management influence of online advertising - a study of white-collar workers in online advertising context", Master dissertation, University of Halmstad, Halmstad, Sweden.

Maddox, L.M. and Gong, W. (2005), "Effects of URLS in traditional media advertising in China", International Marketing Review, Vol. 22 No. 6, pp. 673-692.

Maio, G.R. and Haddock, G. (2015), The Psychology of Attitudes \& Attitude Change, 2nd ed., Sage, Los Angeles, CA.

Malthouse, E.C., Haenlein, M., Skiera, B., Wege, E. and Zhang, M. (2013), "Managing customer relationships in the social media era: introducing the social CRM house", Journal of Interactive Marketing, Vol. 27 No. 4, pp. 270-280.

Maree, K. (2007), First Steps in Research, Van Schaik, Pretoria. 
Matthee, C. (2011), "Towards the two-way symmetrical communication model: The use of social media to create dialogue around brands", Master dissertation, Nelson Mandela Metropolitan University, Port Elizabeth, SA.

Mehta, A. (2000), "Advertising attitudes and advertising effectiveness", Journal of Advertising Research, pp. 67-72.

Meyerson, M. (2010), Success Secrets of Social Media Marketing Superstars, Entrepreneur Press, New York, NY.

Moore, M. (2012), "Interactive media usage among Millennial consumers", Journal of Consumer Marketing, Vol. 29 No. 6, pp. 436-444.

Mulero, O. and Adeyeye, M. (2013), "An empirical study of user acceptance of online social networks marketing”, SACJ, Vol. 50, pp. 6-14.

Murphy, K. (2014), "The influence of content generation on brand attitude and purchase intention within visual social media”, MBA thesis, Dublin Business School, Dublin.

Nhlapo, S. (2015), "Millennials forsake TV for smart devices", available at: www.bizcommunity.com/ Article/196/347/126519.html\#more (accessed 24 June 2016).

Okazaki, S. and Taylor, R.T. (2013), "Social media and international advertising: theoretical challenges and future directions", International Marketing Review, Vol. 30 No. 1, pp. 56-71.

Pallant, J. (2010), SPSS Survival Manual, 4th ed., McGraw-Hill, New York, NY.

Pescher, C., Reichhart, P. and Spann, M. (2014), "Consumer decision-making processes in mobile viral marketing campaigns", Journal of Interactive Marketing, Vol. 28 No. 1, pp. 43-54.

Peters, K., Chen, Y., Kaplan, A.M. Ognibeni, B. and Pauwels, K. (2013), "Social media metrics - a framework and guidelines for managing social media", Journal of Interactive Marketing, Vol. 27 No. 4, pp. 281-298.

Petzer, D.J. and De Meyer, C.F. (2013), "Trials and tribulations: marketing in modern South Africa", European Business Review, Vol. 25 No. 4, pp. 382-390.

Pew Research Centre (2015), "Young adults more likely to own smartphone than PC", available at: www.emarketer.com/Article/Young-Adults-More-Likely-Own-Smartphone-Than-PC/1013202?ecid= NL1002 (accessed 1 July 2016).

Pombo, A. (2015), "Youth marketers, Here's why traditional advertising doesn't cut it anymore. ..", available at: www.bizcommunity.com/Article/196/347/127714.html\#more (accessed 20 July 2016).

Radebe, K. (2013), "Young, middle class and black", available at: www.moneyweb.co.za/moneywebeconomic-trends/young-middle-class-and-black (accessed 14 July 2016).

Ruane, L. and Wallace, E. (2013), "Generation Y females online: insights from brand narratives", Qualitative Market Research: An International Journal, Vol. 16 No. 3, pp. 315-335.

Safko, L. (2010), The Social Media Bible: Tactics, Tools \& Strategies for Business Success, 2nd ed, Wiley, Hoboken, NJ.

Sago, B. (2013), "Factors influencing social media adoption and frequency of use", International Journal of Business and Commerce, Vol. 3 No. 1, pp. 1-14.

Schivinski, B. and Dabrowski, D. (2015), "The impact of brand communication on brand equity through Facebook", Journal of Research in Interactive Marketing, Vol. 9 No. 1, pp. 31-53.

Shevel, A. (2013), "Black Diamonds outshine whites", available at: www.bdlive.co.za/national/2013/ 04/28/black-diamonds-outshine-whites (accessed 13 July 2016).

Statista (2015), "Global social networks ranked by number of users 2015", available at: www.statista. com/statistics/272014/global-social-networks-ranked-by-number-of-users/ (accessed 18 June 2016).

Statistics South Africa (2012), Census 2011: In Brief, Statistics South Africa, Pretoria.

Stokes, R. (2013), eMarketing: The Essential Guide to Marketing in a Digital World, 5th ed., Quirk Education, Cape Town.

Swanepoel, H. (2015), "Full adoption of mobile marketing in Africa", available at: www.bizcommunity. com/Article/196/687/122736.html\#more (accessed 14 July 2016). 
Tan, W.J., Kwek, C.L. and Li, Z. (2013), "The antecedents of effectiveness interactive advertising in the social media", International Business Research, Vol. 6 No. 3, pp. 88-98.

Tennant, J. (2016), "Marketing to the next generation", available at: www.bizcommunity.com/Article/ 196/758/146420.html\#more (accessed 28 September 2016).

Tham, A., Croy, G. and Mair, J. (2013), "Social media in destination choice: distinctive electronic word-of-mouth dimensions", Journal of Travel \& Tourism Marketing, Vol. 30, pp. 144-155.

Thomas, L. (2011), The McGraw-Hill 36-Hour Course: Online Marketing, McGraw-Hill, New York, NY.

Uitz, I. (2012), "Social media: is it worth the trouble?", Journal of Internet Social Networking and Virtual Communities, pp. 1-14.

Walter, E. (2014), "The growing social media power of women and marketing strategies for reaching them", available at: www.clickz.com/clickz/column/2321529/the-growing-social-media-power-ofwomen-and-marketing-strategies-for-reaching-them (accessed 13 June 2016).

Weilbacher, W.M. (2001), "Point of view: does advertising cause a hierarchy of effects?", Journal of Advertising Research, Vol. 41 No. 6, pp. 19-26.

Wharton University of Pennsylvania (2015), "Millennials on steroids': is your brand ready for Generation Z?", available at: http://knowledge.wharton.upenn.edu/article/millennials-on-steroids-is-your-brandready-for-generation-z/ (accessed 26 June 2016).

Williams, A. (2015), "Move over, millennials, here comes Generation Z", available at: www.nytimes. com/2015/09/20/fashion/move-over-millennials-here-comes-generation-z.html?_r=0 (accessed 12 June 2016).

Wright, R. (2006), Consumer Behaviour, Thomson Learning, London.

Wronski, M. (2015), "A glimpse of the SA social media landscape in 2015", available at: www. bizcommunity.com/Article/196/669/133911.html\#more (accessed 6 July 2016).

Yaakop, A., Anuar, M.M. and Omar, K. (2013), "Like it or not: issue of credibility in Facebook advertising", Asian Social Science, Vol. 9 No. 3, pp. 154-163.

Yang, T. (2012), "The decision behaviour of Facebook users", Journal of Computer Information Systems, Vol. 52 No. 3, pp. 50-59.

Yoo, C.Y., Kim, K. and Stout, P.A. (2010), "Assessing the effects of animation in online banner advertising: hierarchy effects model”, Journal of Interactive Advertising, Vol. 4 No. 2, pp. 49-60.

Zikmund, W.G. and Babin, B.J. (2007), Essentials of Marketing Research, 3rd ed., Thomson, Mason, $\mathrm{OH}$. 


\section{Appendix}

Table Al Cronbach's alpha coefficient for social media marketing communication attitude component constructs

Awareness (cognitive) - 0.881

Advertisements on social media are effective in creating awareness of brands correlation item deleted

Advertising on social media alerts me to new company offerings

I have not become aware of new advertisements on social media*

Advertisements on social media attract my attention to certain brands

I cannot recall any advertisements on social media*

I view/click on advertisements on social media because they attract my attention

I can remember several advertisements that I see on social media

Advertising on social media does not alert me to new products*

0.704

0.491

0.662

0.687

0.647

0.666

0.679

0.634

0.583

0.601

0.541

0.606

0.657

0.523

0.543

0.618

0.635

0.618

0.312

0.664

0.556

0.620

0.435

0.265

0.225

0.591

0.554

0.210

0.590

0.615

0.598

0.618

0.722

0.746

0.705

0.746

0.557

0.723

0.718

0.490
0.862

0.880

0.865

0.863

0.867

0.865

0.864

0.868

0.839

0.837

0.843

0.837

0.831

0.845

0.843

0.836

0.743

0.745

0.787

0.738

0.754

0.745

0.772

0.792

0.786

0.735

0.740

0.789

0.735

0.731

0.733

0.730

0.875

0.873

0.876

0.873

0.888

0.875

0.875

0.894

(continued) 
Table Al

Purchase (behavioral) - 0.811

I buy products that are advertised on social media

0.652

0.635

0.218

0.592

0.656

0.104

0.665

0.644
0.713

0.716

0.779

0.723

0.712

0.793

0.711

0.714

Note: *Negatively phrased statement scores were recoded

\section{About the author}

Dr Rodney Graeme Duffett is a senior lecturer in the Faculty of Business and Management Sciences at the Cape Peninsula University of Technology, Cape Town, South Africa. He has published in the following accredited journals: Internet Research, The African Journal of Information Systems, Electronic Commerce Research, The Electronic Journal of Information Systems in Developing Countries, The Retail and Marketing Review, Journal of Contemporary Management, African Journal of Business Management and Southern African Business Review. He has also reviewed papers for several international journal publishers, namely Emerald and Springer. His main research interest is on any form of social media marketing communications. Rodney Graeme Duffett can be contacted at: duffetr@cput.ac.za

For instructions on how to order reprints of this article, please visit our website: www.emeraldgrouppublishing.com/licensing/reprints.htm Or contact us for further details: permissions@emeraldinsight.com 